\title{
A sombra os acolherá
}

\section{Lucas Florêncio}

Descia do céu o véu inconfundível do entardecer, embora os ponteiros anônimos marcassem 4 horas da tarde. $O$ vento dançava com os galhos e folhas de uma frondosa e antiquíssima arvore que havia sido plantada naquele largo há mais de um século, na época em que os escravos faziam dali um recanto único. $O$ enorme Jacarandá fora plantado em lugar estratégico, pois suas colossais raízes se encostavam às paredes em taipa de pilão da Igreja Nossa Senhora do Rosário dos Homens Pretos que havia sido erguida pelos mesmos braços negros que plantaram a frondosa árvore.

E foi nesse cenário, durante aquele frio entardecer que, diante dos meus olhos se desenhou a história e assim me vi testemunha casual de tal poesia. $\mathrm{E}$ embora houvessem ali outras tantas 'almas vivas', é verdade, sem mentira que apenas eu e Gervásio Ferreira, um conhecido embelezador de ruas, conseguimos presenciar de verdade o ocorrido. E assim, impelido pela magia presente no cotidiano, deixo nas linhas que se seguem algumas de minhas lembranças sobre essa história; história esta que me inundou a mente com o pensamento do filósofo desconhecido que supostamente teria dito: "o cotidiano é onde tudo acontece e ninguém vê". Que preciso pensamento!

A realidade é que meu primeiro fragmento de memória sobre o ocorrido é o de estar a alguns metros do extraordinário Jacarandá. Recordo de ver em minhas roupas a projeção das sombras dançantes das folhas da tal árvore. Que desenhos! O volumoso tronco era uma real poesia do tempo, pois eram tantas marcas e figurações em sua extensão que não se podia deixar de pensar quanto de existência cada uma delas tinha. Depois disso, lembro-me, com certa exatidão preguei os olhos a contemplar o que se passava ali diante de mim. Quem pode dizer que a vida as vezes não é irresistível!?

O habitual aspecto bucólico do Largo do Rosário havia desaparecido sem, contudo, deixar de haver naquele lugar certo aspecto gracioso. Os protagonistas inconscientes de tal história estavam sob a tênue sombra da colossal arvore. Eles eram muitos, contavam-se mais ou menos uns trinta. Não há dúvidas de que todos eles estavam à parte do tempo que transcorria: estavam mesmo imersos em outra realidade mental, transitavam numa distinta dimensão do espaçotempo. As vozes deles não ecoavam na agonia daquele cenário, os gestos não se sustentavam no lamentoso vento que ao mesmo tempo os envolvia e repelia. Imersos numa outra dimensão, talvez perceptível somente à eles, o grupo se 
construía como uma realidade momentaneamente flutuante. Uma fotografia em sépia que se destaca ante as coloridas. Eram eles, um grupo de bolivianos em pleno Largo: uma singular alucinação? Não! Não o eram! Eram de modo certo e muito verdadeiro, um fato!

Ali estavam eles, diante dos meus olhos. Um grupo unívoco e fervoroso de bolivianos, que compartilhavam mais do que o local de nascimento; comungavam também a prática não palpável de uma suposta religiosidade. Eram todos, naquele grupo, evangélicos, no sentido que nós, nascidos do lado de cá da fronteira, atribuímos ao termo. Todos, em trajes sociais: os homens, em sua maioria, portando ternos cinza ou pretos de cortes retos e muito bem feitos e as mulheres, todas elas, carregando cumpridas saias que competiam em comprimento somente com os longos e negros cabelos que expunham. Estavam todos, homens e mulheres, com as atenções corpórea e não corpórea voltadas à um mesmo ponto; ponto este onde um improvisado púlpito se materializava, imponente e imóvel frente à diversas bandeiras. Entre as bandeiras e o pequenino púlpito desenhavam-se as silhuetas de alguns músicos que davam cabo de por em musica aquele momento. Faziam assim, o acompanhamento do simplório culto.

Estavam ali, imersos em seu culto que se realizava no Largo do Rosário de Nossa Senhora da Penha. Contavam-se agora, transcorridos alguns minutos desde minha primeira revista do cenário, uns quarenta e tantos bolivianos. E que expressão essa: "quarenta e tantos bolivianos"! Nosso olhar é tão supérfluo, que há sempre certa arbitrariedade por de trás destas expressões! Mas ora, quem em sã consciência há de dizer que as palavras conseguem traduzir toda complexidade de nosso mundo? Talvez, o que é realmente essencial escape à palavra!

Mas voltemos a resgatar da memória o que tenho sobre a história!

Eles estavam ali. Quero dizer, os bolivianos estavam ali! E como é espantoso quando certas singularidades se põem diante de nossas vistas. Pois aquele não era um lugar qualquer. Bem ali, onde antigamente os escravos ajuntavam-se para reencenar o elo com seus ancestrais, transformando-se pela fé em comunidade espiritual, estavam agora os oriundos do país de "el hado propicio". Ali, naquele Largo, onde a sombra daquele mesmo Jacarandá havia se deitado sob as costas negras. O cotidiano não é todo banalidade!

E aquele Largo, que havia sido o espaço de comunhão espiritual dos escravos, o cenário onde as mãos negras ávidas pela perpetuação de sua cultura desenharam na paisagem uma Igreja... tinha se tornado o palco para encenação espiritual de outro grupo, os bolivianos! Logo eles... Quantas contradições e coincidências não estão contidas na subjetividade da vida cotidiana! Como não deixar o pensamento fluir a tal reflexão? Como não pensar na memória da 
violência contra a humanidade, que veste a sórdida máscara da escravidão e da servidão?

O tempo, dimensão translúcida de nosso viver, impunha sua presença pelas sombras do inexplicável Jacarandá, que agora deitavam-se por quase todo o Largo. As badaladas ressonantes da Igreja anunciavam também que certo tempo já havia se esvaído desde que parara para olhar a cena.

O culto seguiu, acompanhado pelas nuances do entardecer. Já a essa altura todos eles eram abraçados pela profusa sombra do Jacarandá, que servia como uma espécie de referencial para todos ali. Suas vistosas raízes, seu generoso tronco, sua copa abundante pareciam nos transmitir uma tímida mensagem de paz e ordem. O Jacarandá nos oferecia um sentido de ordem invisível, que em meio aquele cotidiano tão desordenado soava como um alento passageiro, porém reconfortante. E conforme foi, os bolivianos seguiram com suas orações, imersos em suas prospecções espirituais. O idioma, elo simbólico para o grupo, era somente mais uma ponte entre todos daquele unívoco coletivo. Intenções, olhares, gestos, silêncios... tudo isso os colocavam em unidade, de modo que pareciam mesmo não estar dentro de nossa ordem temporal.

E assim seguiu! Cantos, louvores, meditações... o culto se esvaia no tempo e espaço criando uma cena oportuna e atraente para qualquer transeunte. Contudo, aos olhos deste que escreve parecia que os bolivianos não eram percebidos pelos que por ali passavam, ao contrário, os olhares das pessoas buscavam pelo desencontro com a cena. As visões que poderiam ser e não o eram mostravam-me o quanto a ideia de "outro" é rasa.

E assim, posso dizer com relativa precisão, do mesmo modo como os escravos, os bolivianos teriam naquele espaço um lugar medido e sensível à suas vidas, a seus sofrimentos e à suas causas e embora excluídos de toda sociabilidade concernente ao cotidiano, havia ali algo que os acolhera... a sombra do velho Jacarandá. 